\title{
Estimation of length-weight relationship and condition factor of spotted snakehead Channa punctata (Bloch) under different feeding regimes
}

\author{
Surjya Narayan Datta*, Vaneet Inder Kaur, Asha Dhawan and Geeta Jassal
}

\begin{abstract}
Comparative study was conducted to observe the efficacy of different feeding regimes on growth of Channa punctata. Six iso- proteinous diets were prepared by using different agro industrial by-products. Maximum weight gain was recorded with diet having $66.75 \%$ rice bran, $11.50 \%$ mustard cake, $23.0 \%$ groundnut cake, 5\% molasses, $1.5 \%$ vitamin-mineral mixture and $0.5 \%$ salt with specific growth rate of 0.408 . The experimental fish recorded the value of exponent ' $b$ ' in the range of 2.7675 to 4.3922 . The condition factor ' $K$ ' of all experimental fish was above 1.0 (1.094- 1.235) indicating robustness or well being of experimented fish.
\end{abstract}

Keywords: Channa punctata; Formulated diets; Condition factor; Correlation coefficient; Growth

\section{Introduction}

The spotted snakehead, Channa punctata (Bloch) is well known for its taste, high nutritive value and medicinal qualities (Haniffa et al. 2004) and is recommended as a diet during convalescence (Chakraborty 2006). It is distributed throughout the South-East Asian countries and has been identified as a potential species for rearing in paddy fields, derelict and swampy water as it is an air breathing and hardy fish. It has high market value because of the flavour and availability throughout the year. The fish is suitable for both monoculture and polyculture. Good deal of work has been carried out on different aspects of survival and growth, length-weight relationship, condition factor of C. punctata in India and abroad (Victor and Akpocha 1992; Dutta 1994; Bias et al. 1994; Alam and Parween 2001; Islam et al. 2004; Kumar et al. 2013). However, limited studies are conducted on growth and culture potentiality of this species. Therefore the present work has been carried out to study the efficacy of different formulated diets on survival and growth rate of C. punctata.

\section{Materials and methods}

\section{Experimental setup}

The study was conducted at the Fish Farm of College of Fisheries, Guru Angad Dev Veterinary and Animal Sciences University, Ludhiana (Punjab), India $\left(30.54^{\circ} \mathrm{N}\right.$ latitude, $75.48^{\circ} \mathrm{E}$ longitude and an altitude of $247 \mathrm{~m}$ above mean sea level). The growth of fish was assessed w.r.t. different formulated diets over a period of 90 days. The studies were conducted in PVC cistern $(1.50 \mathrm{~m} \times 1.0 \mathrm{~m} \times 1.0 \mathrm{~m})$ in triplicate. $5 \mathrm{~cm}$ soil bed was provided in each cistern and water depth was maintained $50 \mathrm{~cm}$ throughout the study period. Each cistern was stocked with 25 fingerlings (average length $=11.645 \pm 0.3145 \mathrm{~cm}$, average wt. $=11.961 \pm 0.1348 \mathrm{~g})$ of Channa punctata collected from wild source.

\section{Formulated diets}

Six isonitrogenous diets $(33.19$ - 35.23\% crude protein on dry weight basis) i.e. $D_{1}, D_{2}, D_{3}, D_{4}, D_{5}$ and $D_{6}$ were formulated using agroindustrial byproducts like rice bran, mustard cake, fish meal, ground nut cake and soybean meal (Tables 1 and 2). For preparation of diets, all feed ingredients (dry) were first grounded to a small particle size in a laboratory electric grinder and sieved through an approximately $250 \mu \mathrm{m}$ sieve. Ingredients were thoroughly mixed in a food mixer for 15 minutes. Enough water was slowly added to make stiff dough.

\footnotetext{
* Correspondence: surjya30740@gmail.com

College of Fisheries, Guru Angad Dev Veterinary and Animal Sciences University, Ludhiana, Punjab 141004, India
} 
Table 1 Percent composition of experimental diets

\begin{tabular}{lllllll}
\hline Ingredients & $\mathbf{D}_{\mathbf{1}}$ & $\mathbf{D}_{\mathbf{2}}$ & $\mathbf{D}_{\mathbf{3}}$ & $\mathbf{D}_{\mathbf{4}}$ & $\mathbf{D}_{\mathbf{5}}$ & $\mathbf{D}_{\mathbf{6}}$ \\
\hline Rice bran & 67.11 & 73.15 & 66.75 & 76.49 & 71.86 & 69.29 \\
Mustard cake & 10.85 & 26.92 & 11.50 & 7.84 & 9.38 & 10.46 \\
Fish meal & 21.70 & - & - & - & - & 6.75 \\
Groundnut cake & - & - & 23.0 & - & 9.38 & 6.75 \\
Soybean meal & - & - & - & 9.38 & 1.88 & 6.75
\end{tabular}

Additives in all diets: Vitamin-mineral mixture $=1.5 \%$, Salt $=0.5 \%$, Molasses $=5 \%$.

The wet mixture was steamed for 5 minutes and the diets were produced in a noodle-like shape of $2.0 \mathrm{~mm}$ in diameter using a meat grinder. The pelleted diets were dried overnight at $55^{\circ} \mathrm{C}$ afterwards were broken up and sieved into appropriate pellet sizes. Proximate composition of feed ingredients and formulated diets was determined following the standard methods of AOAC (2005).

\section{Feeding of fish}

Fish were fed with formulated diets @ 2\% of body weight at 10 am daily. The feed quantity was regulated based on the fortnightly sampling of 10 fingerlings from each treatment.

\section{Water analysis}

Throughout the study period physico-chemical parameters of water samples including water temperature, $\mathrm{pH}$, dissolved oxygen, total alkalinity, hardness, $\mathrm{NH}_{3}-\mathrm{N}$, $\mathrm{NO}_{3}-\mathrm{N}, \mathrm{NO}_{2}-\mathrm{N}$ and $\mathrm{PO}_{4}-\mathrm{P}$ were measured following standard methods (APHA 2005).

\section{Growth analysis}

Fish were measured in terms of weight gain and increase in length. Total length (TL) was measured to the nearest
$0.1 \mathrm{~mm}$ using a $30 \mathrm{~cm}$ ruler as the distance from the tip of the anterior most part of the body to the tip of the caudal fin. Analytical balances with precision of $0.01 \mathrm{~g}$ were used to record body wet weight (BW).

\section{Following growth analysis were calculated}

i. Specific growth rate $(\mathrm{SGR})=\frac{\text { Loge (Final weight)-Loge (Initial weight) }}{\text { Culture days }} \times 100$ Where, weight recorded in gram.

ii. Length-weight relationship: The length-weight (log-transformed) relationships were determined by linear regression analysis and scatter diagrams of length and weight were plotted. The length-weight relationship of the experimented fish is worked out as per cube law given by Le Cren (1951).

$$
\mathrm{W}=a \mathrm{~L}^{\mathrm{b}}
$$

Where, W=Weight of fish (g), L is observed total length $(\mathrm{cm})$, ' $\mathrm{a}$ ' is the regression intercept and ' $\mathrm{b}$ ' is the regression slope.

The logarithmic transformation of the above formula is-

$$
\log \mathrm{W}=\log \mathrm{a}+\mathrm{b} \log \mathrm{L}
$$

iii. Fulton's condition factor (K): Fulton's condition factor (K) was calculated according to Htun-Han (1978) equation as per formula given below:

$$
\mathrm{K}=\frac{\mathrm{W} \times 100}{\mathrm{~L} 3}
$$

Where, W=weight of fish (g), L=Length of fish $(\mathrm{cm})$.

\section{Statistical analysis}

The analysis of covariance was performed to determine variation in 'b' values for each species following method of

\begin{tabular}{|c|c|c|c|c|c|c|}
\hline Ingredients & Moisture & Crude protein & Ether extract & Crude fibre & Ash & NFE \\
\hline Rice bran & 14.20 & 26.70 & 1.4 & 8.89 & 7.18 & 41.63 \\
\hline Mustard cake & 13.20 & 57.53 & 1.5 & 7.58 & 7.22 & 12.97 \\
\hline Fish meal & 14.65 & 46.80 & 3.0 & 2.99 & 29.76 & 3.25 \\
\hline Groundnut cake & 13.95 & 44.59 & 2.5 & 7.81 & 4.21 & 26.94 \\
\hline Soybean meal & 13.05 & 66.48 & 1.5 & 5.73 & 5.26 & 8.01 \\
\hline$D_{1}$ & 16.00 & 34.22 & 2.66 & 7.68 & 16.12 & 23.32 \\
\hline$D_{2}$ & 17.25 & 33.68 & 1.45 & 10.68 & 7.14 & 30.29 \\
\hline$D_{3}$ & 17.00 & 34.10 & 1.90 & 9.73 & 5.80 & 30.34 \\
\hline $\mathrm{D}_{4}$ & 15.10 & 33.94 & 1.12 & 9.36 & 5.48 & 35.60 \\
\hline$D_{5}$ & 15.15 & 33.74 & 1.75 & 9.49 & 6.13 & 33.94 \\
\hline$D_{6}$ & 14.85 & 34.35 & 1.95 & 9.23 & 10.34 & 28.49 \\
\hline
\end{tabular}
Snedecor and Cochran (1967). The statistical significance

Table 2 Proximate composition (\% DM basis) of feed ingredients and experimental diets 
Table 3 Water quality parameters of different treatments

\begin{tabular}{lllllll}
\hline Tanks & $\mathbf{D}_{\mathbf{1}}$ & $\mathbf{D}_{\mathbf{2}}$ & $\mathbf{D}_{\mathbf{3}}$ & $\mathbf{D}_{\mathbf{4}}$ & $\mathbf{D}_{\mathbf{5}}$ & $\mathbf{D}_{\mathbf{6}}$ \\
\hline Temperature ${ }^{\circ} \mathrm{C}$ & $30.450 \pm 2.717$ & $30.612 \pm 2.717$ & $30.269 \pm 2.294$ & $29.821 \pm 2.363$ & $29.22 \pm 1.683$ & $29.672 \pm 1.959$ \\
$\mathrm{pH}$ & $8.070 \pm 0.403$ & $8.110 \pm 0.428$ & $8.204 \pm 0.386$ & $8.171 \pm 0.382$ & $8.217 \pm 0.376$ & $8.242 \pm 0.369$ \\
DO $(\mathrm{mg} / \mathrm{l})$ & $2.355 \pm 1.316$ & $2.202 \pm 1.356$ & $3.059 \pm 1.401$ & $2.611 \pm 2.050$ & $2.989 \pm 2.187$ & $3.469 \pm 2.694$ \\
Alkalinity $(\mathrm{mg} / \mathrm{l})$ & $411.090 \pm 43.994$ & $424.363 \pm 43.797$ & $363.272 \pm 72.901$ & $425.45 \pm 46.79$ & $445.09 \pm 45.889$ & $404.00 \pm 36.57$ \\
Hardness $(\mathrm{mg} / \mathrm{l})$ & $378.667 \pm 23.626$ & $340.000 \pm 11.313$ & $373.332 \pm 26.599$ & $372.00 \pm 37.09$ & $362.00 \pm 28.33$ & $349.33 \pm 24.07$ \\
Ammonia $(\mathrm{mg} / \mathrm{l})$ & $0.3591 \pm 0.124$ & $0.4245 \pm 0.116$ & $0.320 \pm 0.111$ & $0.3409 \pm 0.114$ & $0.3273 \pm 0.117$ & $0.2909 \pm 0.108$ \\
Phosphate $(\mathrm{mg} / \mathrm{l})$ & $1.750 \pm 0.765$ & $1.540 \pm 0.745$ & $1.654 \pm 0.782$ & $1.622 \pm 0.707$ & $1.582 \pm 0.718$ & $1.613 \pm 0.773$ \\
Nitrite $-\mathrm{NO}_{2}(\mathrm{mg} / \mathrm{l})$ & $0.197 \pm 0.222$ & $0.182 \pm 0.222$ & $0.116 \pm 0.222$ & $0.114 \pm 0.222$ & $0.077 \pm 0.222$ & $0.165 \pm 0.222$ \\
Nitrate $-\mathrm{NO}_{3}(\mathrm{mg} / \mathrm{l})$ & $0.308 \pm 0.322$ & $0.340 \pm 0.447$ & $0.396 \pm 0.428$ & $0.395 \pm 0.361$ & $0.393 \pm 0.389$ & $0.349 \pm 0.406$ \\
\hline
\end{tabular}

Values are Mean \pm Standard Deviation.

of the isometric exponent (b) was analyzed by a function: ts $=(b-3) / S_{b}$ (Sokal and Rohlf 1987), where ts is the 't' student statistics test value, ' $b$ ' is the slope and $S_{b}$ is the standard error of ' $b$ '. The comparison between obtained values of t-test and the respective critical values allowed the determination of the ' $\mathrm{b}$ ' values statistically significant and their inclusion in the isometric range $(b=3)$ or allometric range (negative allometric; $b<3$ ). Statistical software SPSS 14 and PAST Ver. 1.8 used for analysing the data.

\section{Results and discussion}

Lower dissolved oxygen content of water did not create any adverse effect on survival and growth of fish because of the accessory respiratory organ present in Channa punctata (Table 3). There were no significant differences in water quality parameters viz. temperature, $\mathrm{pH}$, dissolved oxygen, total alkalinity, Hardness, $\mathrm{NH}_{3}-\mathrm{N}, \mathrm{NO}_{3}-\mathrm{N}, \mathrm{NO}_{2}$ $\mathrm{N}$ and $\mathrm{PO}_{4}-\mathrm{P}$ observed among different treatments and all these parameters (except dissolved oxygen content) were within the range as suggested by Boyd and Pillai (1984); Rowland (1986) and Boyd and Tucker (1998) but significant variation was observed within a single treatments in time series data of different parameters.

$100 \%$ survival of fish was observed in all treatments. Specific growth rate was observed maximum in $\mathrm{D}_{3}$ followed by $D_{4}, D_{5}, D_{2}, D_{6}$ and $D_{1}$, respectively (Table 4 ). Initial and final average weight (g), Length - weight rela- co-efficient ' $\mathrm{b}$ ' and logarithmic relationship between length and weight with regression equation is given in Tables 5, 4 and Figure 1 . In the present study final ' $b$ ' varied between 2.7675 to 4.3922 . Growth is said to be positive allometric when the weight of an organism increases more than length $(b>3)$ and negative allometric when length increases more than weight $(b<3)$ (Wootton 1992). When TL was regressed with BW, the slope value was significantly lower than critical isometric value i.e. 3, in treatment $D_{1}$ and $D_{6}$ indicating negative algometric growth; thus species become slender as it increases in length (Pauly 1984) where as b value was higher than 3 in $D_{2}, D_{3}, D_{4}$ and $D_{5}$ treatment, indicating the species becomes heavier for its weight, as it grows longer (Thakur and Das 1974). The results of the present study is in conformity with the views of Le Cren (1951) and Chauhan (1987) that a fish normally does not retain the same shape or body outline throughout their lifespan and specific gravity of tissue may not remain constant, the actual relationship may depart significantly from the cube law. Negative allometric growth pattern have been reported in C. punctata by Haniffa et al. (2006) and Ali et al. (2002). Negative allometric growth has also been reported in $C$. maurulius (Dua and Kumar 2006; Rathod et al. 2011) and in C. Striatus (Khan et al. 2011). Variation in slope may be attributed to sample size variation, life stages and environmental factors (Kleanthids et al. 1999). The higher slope

Table 4 Final length weight relationship of fishes reared in experimental tanks

\begin{tabular}{|c|c|c|c|c|c|c|c|}
\hline Tank & $\begin{array}{l}\text { Final average } \\
\text { weight }(\mathbf{g})\end{array}$ & $\begin{array}{l}\text { Specific growth } \\
\text { rate }(\% / \text { day })\end{array}$ & $\begin{array}{c}\text { Logarithmic equation Log } \\
W=\log a+b \log L\end{array}$ & $\begin{array}{c}\text { Correlation } \\
\text { coefficient ' } r \text { ' }\end{array}$ & $\begin{array}{c}\text { Coefficient of } \\
\text { determination ' } \mathrm{r}^{2} \text { ' }\end{array}$ & Condition factor ' $\mathrm{K}$ ' & 'b' \\
\hline $\mathrm{D}_{1}$ & 21.67 & 0.281 & $\log W=\log 0.0151+2.7675 \log L$ & 0.789 & 0.622 & 1.094 & 2.767 \\
\hline $\mathrm{D}_{2}$ & 24.25 & 0.334 & $\log W=\log 0.0003+4.3922 \log L$ & 0.930 & 0.865 & 1.116 & 4.392 \\
\hline$D_{3}$ & 27.77 & 0.408 & $\log W=\log 0.0011+3.866 \log L$ & 0.939 & 0.881 & 1.210 & 3.866 \\
\hline$D_{4}$ & 25.66 & 0.376 & $\log W=\log 0.0012+3.820 \log L$ & 0.944 & 0.892 & 1.171 & 3.820 \\
\hline$D_{5}$ & 24.66 & 0.346 & $\log W=\log 0.0042+3.3254 \log L$ & 0.876 & 0.768 & 1.334 & 3.325 \\
\hline$D_{6}$ & 22.16 & 0.302 & $\log W=\log 0.0118+2.888 \log L$ & 0.913 & 0.834 & 1.235 & 2.888 \\
\hline
\end{tabular}


Table 5 Initial length weight relationship of fishes reared in experimental tanks

\begin{tabular}{cccc}
\hline Tank & $\begin{array}{c}\text { Initial average } \\
\text { weight }(\mathbf{g})\end{array}$ & $\begin{array}{c}\text { Initial logarithmic equation } \\
\text { Log } \mathbf{W}=\log \mathbf{a}+\mathbf{b} \log \mathrm{L}\end{array}$ & $\begin{array}{c}\text { Initial 'b' } \\
\text { value }\end{array}$ \\
\hline $\mathrm{D}_{1}$ & 12.09 & $\log \mathrm{W}=\log 0.0288+2.474 \log \mathrm{L}$ & 2.474 \\
$\mathrm{D}_{2}$ & 12.13 & $\log \mathrm{W}=\log 0.0117+2.862 \log \mathrm{L}$ & 2.862 \\
$\mathrm{D}_{3}$ & 11.91 & $\log \mathrm{W}=\log 0.012+2.851 \log \mathrm{L}$ & 2.851 \\
$\mathrm{D}_{4}$ & 11.76 & $\log \mathrm{W}=\log 0.0014+3.775 \log \mathrm{L}$ & 3.775 \\
$\mathrm{D}_{5}$ & 12.04 & $\log \mathrm{W}=\log 0.0104+2.917 \log \mathrm{L}$ & 2.917 \\
$\mathrm{D}_{6}$ & 11.84 & $\log \mathrm{W}=\log 0.0107+2.925 \log \mathrm{L}$ & 2.925 \\
\hline
\end{tabular}

of C. punctata in $\mathrm{D}_{2}, \mathrm{D}_{3}, \mathrm{D}_{4}$ and $\mathrm{D}_{5}$ reflect the faster growth compared to $\mathrm{D}_{1}$ and $\mathrm{D}_{6}$ in the present study.

The condition factor $(\mathrm{K})$ of a fish reflects physical and biological circumstances and fluctuations by interaction among feeding conditions, parasitic infections and physiological factors (Le Cren 1951). This also indicates the changes in food reserves and therefore an indicator of the general fish condition. Moreover, body condition provides an alternative to the expensive in vitro proximate analyses of tissues (Sutton et al. 2000). Therefore, information on condition factor can be vital to culture system management because they provide the producer with information of the specific condition under which organisms are developing (Araneda et al. 2008). The values of condition factor ' $\mathrm{K}$ ' recorded in the present study are 1.094, 1.116, $1.210,1.171,1.334$ and 1.235 in $D_{1}, D_{2}, D_{3}, D_{4}, D_{5}$ and $\mathrm{D}_{6}$, respectively. Condition factor of greater than one showed the well being of fishes fed with different experimental diets. The values of ' $K$ ' in $D_{2}, D_{3}, D_{4}, D_{5}$ and $D_{6}$ were higher than $D_{1}$, suggesting that fish fed with diet containing different experimental diets (Table 5) were much more robust than the fish fed with diet in $\mathrm{D}_{1}$. The results are conformity with the study of Chandra and

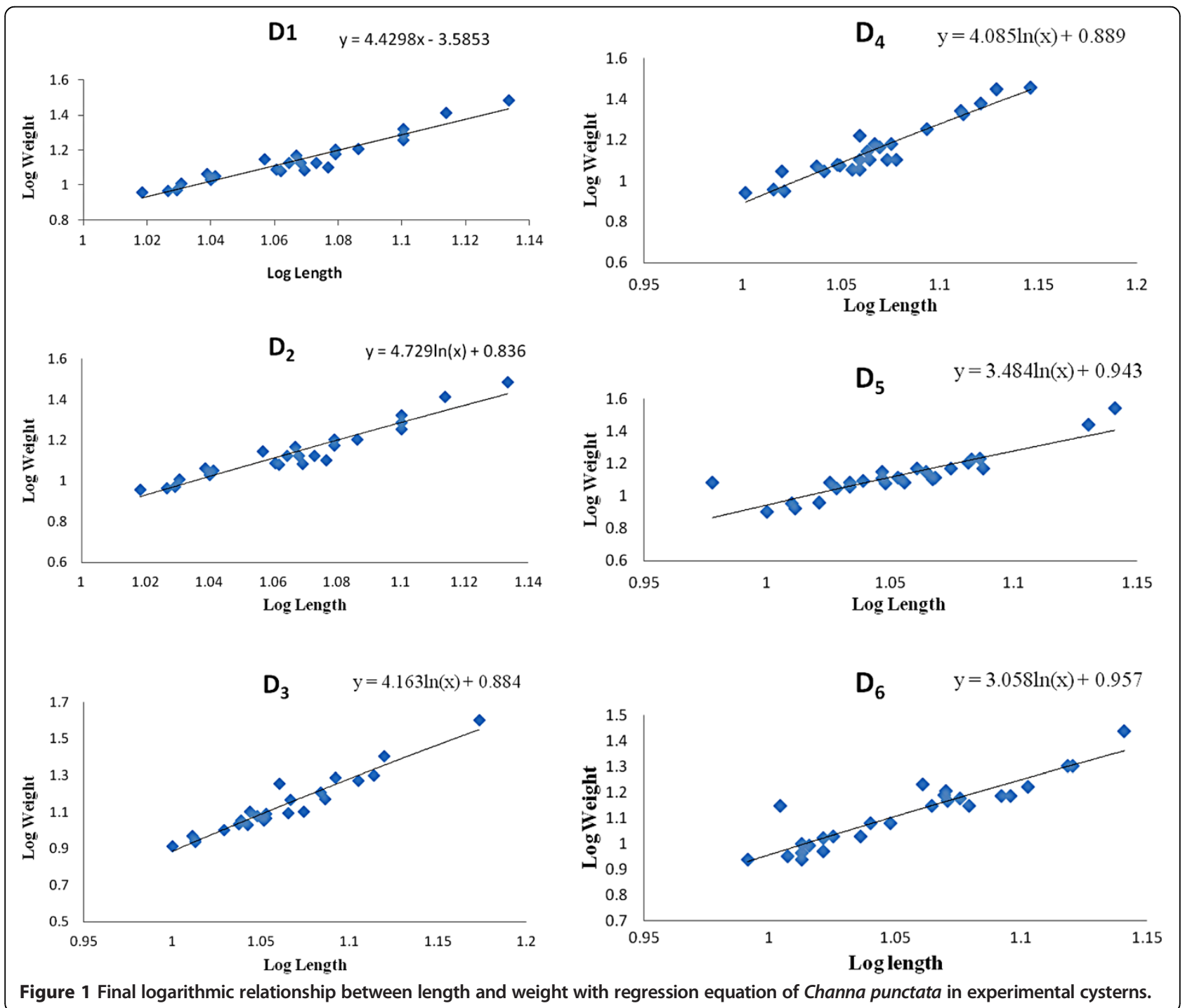


Jhan (2010) who recorded the $K$ value of Channa punctata in the range of $1.05-1.89$.

The co-efficient of determination $\left(\mathrm{r}^{2}\right)$ values explained the proper fit of the model for growth. In the present study, lowest value of $\mathrm{r}^{2}$ of Channa punctata were recorded as 0.622 (62\% variability) in $\mathrm{D}_{1}$ and highest recorded as 0.892 (89\% variability) in $\mathrm{D}_{4}$ (Table 4 ) indicating more than $62 \%$ variability by the model and good fitness.

\section{Conclusions}

In present study, growth rate, condition factor and coefficient of determination value recorded on acclimatization of wild stock of C. punctata under experimental condition indicated a favourable response of the fish to the ecological transition from the wild habitat to the experimental environment. The appreciable growth rate exhibited by the fish during rearing period indicated that the prevailing environmental conditions were within the tolerance range for the species. The findings of the present study support that the species can be cultured in large scale as food fish to meet the nutritional demand.

\section{Competing interests}

The authors declare that they have no competing interests.

\section{Authors' contributions}

$\mathrm{SN}, \mathrm{VI}$ and $\mathrm{A}$ planned and designed the experiment. $\mathrm{G}$ helped in analysis. SN and A wrote the paper. All authors read and approved the final manuscript.

\section{Acknowledgements}

The authors are grateful to Dean, College of Fisheries, GADVASU, Ludhiana for her keen interest and facilities provided for the study.

Received: 27 June 2013 Accepted: 26 August 2013

Published: 4 September 2013

\section{References}

Alam MM, Parween S (2001) Survivality of Channa punctata (Bloch) in Different Kinds of Container. Pak J Zool 33(3):259-260

Ali M, Salam A, labal F, Khan BA (2002) Growth performance of Channa punctata from two ecological regimes of Punjab, Pakistan. Pak J Biol Sci 5(10):1123-1125

AOAC (2005) Official methods of analysis, association of official analytical chemists, 18th edition. AOAC Press, Gaithersburg

APHA (2005) Standard methods for the examination of water and wastewater, 21 st edition. American Public Health Association, Washington, DC

Araneda M, Perez EP, Gasca LE (2008) White shrimp Penaeus vannamei culture in freshwater at three densities: condition state based on length and weight. Aquacult 283:13-18

Bias VS, Thakurm SS, Agarwal NC (1994) Food and Feeding Activity of Channa punctata (Bloch). J Freshwater Biol 6(3):247-251

Boyd CE, Pillai YK (1984) Water quality management in aquaculture. CMFRI Spec Publ 22:97

Boyd CE, Tucker CS (1998) Pond aquaculture water Quality Management. Springer India Pvt Itd, India

Chakraborty NM (2006) Murrels and Murrel Culture. Narendra Publishing House, Delhi

Chandra R, Jhan N (2010) The analysis of length-weight relationship of Channa punctata with relative physico-chemical parameters. J Exp Sci 1(5):4-5

Chauhan RS (1987) Food, parasites and length-weight relationship of a hill stream fish, Schizothorax plagiostomus (Heckel). Indian J Anim Res 21(2):93-96

Dua A, Kumar K (2006) Age and growth patterns in Channa marulius from Harike Wetland (A Ramsar site), Punjab, India. J Environ Biol 27(2):377-380
Dutta SPS (1994) Food and feeding habits of Channa punctata (Bloch) inhabiting Gadigarh Stream, Jammu. J Freshwat Biol 6(4):333-336

Haniffa MA, Marimuthu K, Nagarajan M, Arokiaraj AJ, Kumar D (2004) Breeding behaviour and parental care of the induced breed spotted Murrel Channa punctata under captivity. Curr Sci 86(10):1375-1376

Haniffa MA, Nagarajan M, Gopalakrishnan A (2006) Length-weight relationship of Channa punctata from Western Ghat Rivers of Tamil Nadu. J Appl Ichthyol 22:308-309

Htun-Han M (1978) The reproductive biology of the dab Limanda limanada (L.) in the North Sea: gonadosomatic index, hepatosomatic index and condition factor. J Fish Biol 13(1):351-377

Islam MN, Parween S, Hyder F, Flowra FA, Musad AA (2004) Food and feeding habit of juvenile Channa punctata (Bloch) from a semi closed water body in Chalan Beel Floodplain, Bangladesh. J Biol Sci 4(3):352-356

Khan S, Khan MA, Miyan K, Mubark M (2011) Length weight relationships for nine freshwater teleosts collected from River Ganga, India. J Zool Res 7(6):401-405

Kleanthids PK, Sinis Al, Stergiou KI (1999) Length-weight relationships of freshwater fishes in Greece. Naga, ICLARM Q 22:37-41

Kumar K, Lalrinsanga PL, Sahoo M, Mohanty UL, Kumar R, Sahu AK (2013) Lengthweight relationship and condition factor of Anabas testudineus and Channa Species under different culture systems. World J Fish Marine Sci 5(1):74-78

Le Cren ED (1951) The length-weight relationships and seasonal cycle in gonad weight and condition in the perch (Perca fluviatilis). J Anim Ecol 20:201-219

Pauly D (1984) Fish population dynamics in tropical waters: a manual for use with programmable calculators. ICLARM Stud Rev 8:325

Rathod SR, Shinde SE, More PR (2011) Length-weight relationship in Salmostoma navacula and Channa maurulius Godavari River at Kaigaon Toka, Dist. Aurangabad (M.S.) India. Res Sci Tech 3(3):104-106

Rowland SJ (1986) Site selection, design and operation of aquaculture farms. In: Owen P, Bowden J (ed) Freshwater aquaculture in Australia, Brisbane, 1st edition. Rural Press Queensland, Australia

Snedecor GW, Cochran WG (1967) Statistical methods. Oxford and IBH Publishing Co, New Delhi

Sokal RR, Rohlf FJ (1987) Introduction to biostatistics, 2nd edition. Freeman Publication, New York

Sutton SG, Bult TP, Haedrich RL (2000) Relationships among fat weight, body weight, water weight and condition factors in wild Atlantic salmon parr. T Am Fish Soc 129:527-538

Thakur NK, Das MK (1974) Length-weight relationship of Heteropneustes fossilis (Bloch). J Inland Fish Soc India 6:95-99

Victor R, Akpocha BO (1992) The Biology of Snakehead, Channa obscura (Gunther) in a Nigerian Pond under Monoculture. Aquac 101(1):17-24

Wootton RJ (1992) Fish ecology: tertiary level biology. Blackie, London

\section{doi:10.1186/2193-1801-2-436}

Cite this article as: Datta et al:: Estimation of length-weight relationship and condition factor of spotted snakehead Channa punctata (Bloch) under different feeding regimes. SpringerPlus 2013 2:436.

\section{Submit your manuscript to a SpringerOpen ${ }^{\circ}$ journal and benefit from:}

- Convenient online submission

- Rigorous peer review

- Immediate publication on acceptance

- Open access: articles freely available online

- High visibility within the field

- Retaining the copyright to your article

Submit your next manuscript at $\gg$ springeropen.com 